\title{
РАДІОТЕХНІЧНОМУ ФАКУЛЬТЕТУ КПІ ІМ. ІГОРЯ СІКОРСЬКОГО 90 РОКІВ
}

\section{Р. В. АНТИПЕНКО}

Національний технічний університет Украйни

«Київський політехнічний інститут імені Ігоря Сікорсъкого», Україна, Київ, 03056, пр-т Перемоги 37

\begin{abstract}
Анотація. Стаття містить короткий огляд напрямків наукових досліджень та вагомих досягнень науково-педагогічних працівників радіотехнічного факультету КП ім. Ігоря Сікорського за 90 років його існування. Наведено основні результати наукових робіт останнього десятиліття.
\end{abstract}

Ключові слова: Київськийполітехнічний інститут; радіотехнічний факультет; напрямки наукових досліджень; досягнення; ювілей

У 2020 році радіотехнічному факультету КПІ ім. Ігоря Сікорського виповнилось 90 років. Згадаєм ключові дати в історії становлення та розвитку радіотехнічного факультету $[1,2]$.

Роком заснування радіотехнічного факультету є 1930 р., коли електротехнічний факультет Київського політехнічного інституту було реорганізовано в Київський енергетичний інститут, в якому було створено радіотехнічний факультет і кафедру радіотехніки. Завідувачем кафедри та першим деканом радіотехнічного факультету став професор Володимир Васильович Огієвський.

У 1934 р. Київський енергетичний інститут було реорганізовано у Київський індустріальний інститут, куди радіотехнічний факультет увійшов як спеціальність з кількома лабораторіями: загальної радіотехніки та електровакуумних приладів, приймально-передавальних пристроїв та акустики, радіопередавальних пристроїв, телебачення та джерел живлення.

У 1938 р. радіо-спеціальність у Київському політехнічному інституті перетворено в спеціальний факультет, а з кафедри радіотехніки виділено кафедру приймально-передавальних пристроїв. Завідувачем кафедри став професор Семен Ісакович Тетельбаум.
У 1941 році Київський індустріальний інститут було евакуйовано в м. Ташкент і включено до складу Середньоазійського індустріального інституту. В 1944 р. колектив інституту повернувся до Києва. В післявоєнні роки радіотехнічний факультет (декан - проф. В. В. Огієвський) продовжує свій розвиток. Кафедру приймально-передавальних пристроїв розділено на дві: радіопередавальних пристроїв (зав. каф. - проф. С.I. Тетельбаум) та радіоприймальних пристроїв. Завідувачем цієї кафедри став проф. Наум Пилипович Воллернер. Отже підготовку інженерів вже забезпечували три кафедри радіотехнічного факультету.

У той час значний об'єм наукових робіт по створенню нових потужних електронних пристроїв НВЧ проводився під керівництвом члена-кореспондента Академії наук УРСР C.I. Тетельбаума. Також виконувались вагомі наукові роботи в області радіозв'язку по створенню системи радіопередачі 3 амплітудно-фазовою модуляцією, а також роботи в області Х-променевої томографії.

У 1952 р. до складу радіотехнічного факультету увійшли спеціальності «Діелектрики та напівпровідники» та «Електронні прилади», а в 1962 p. на базі цих кафедр створюється факультет радіоелектроніки. У складі РТФ залишаються чоти- 
ри спеціальні кафедри - теоретичних основ радіотехніки, радіопередавальних пристроїв, радіоприймальних пристроїв та кафедра математичної фізики. Завідувачем кафедри радіопередавальних пристроїв став проф. Вадим Павлович Тараненко.

У 1957 році за досягнуті радіотехнічним факультетом вагомі наукові успіхи Київському політехнічному інституту було доручено видавництво журналу «Известия ВУЗов СССР. Радиотехника», а відповідальним редактором журналу призначено члена-кореспондента АН УРСР проф. C.I. Тетельбаума. 31959 до 1972 р. відповідальним редактором журналу був проф. В. В. Огієвський. Із 1972 до 2009 року головним редактором журналу працював проф. Ярослав Карпович Трохименко. В 2009 р. головним редактором призначено проф. Федора Федоровича Дубровку. Сьогодні журнал є авторитетним міжнародним фаховим виданням, перекладається на англійську мову, та публікується у США за назвою «Radioelectronics and Communications Systems». Журнал входить до наукометричної бази Scopus (квартіль 3, фактор впливу SNIP = 0,51, індекс Гірша 10).

Ще один журнал, що видається на радіотехнічному факультеті, — «Вісник національного технічного університету України «Київський політехнічнй інститут». Серія Радіотехніка. Радіоапаратобудування» - було започатковано в 1956 році. Протягом всього періоду існування журнал був не лише джерелом наукової інформації, але виконував ще одну не менш важливу функцію створення умов для наукової молоді факультету щодо здобуття досвіду публікації отриманих наукових результатів у фахових виданнях. Починаючи з 2012 року концепція видання змінилась 3 орієнтацією на міжнародний рівень. Колектив радіотехнічного факультету забезпечує редакційне проходження, рецензування та науковий рівень статей. Журнал внесено до категорії А переліку наукових фахових видань України, він індексується у Web of Science. Головним редактором журналу є проф. Олег Борисович Шарпан.

Загалом наукова робота завжди була головним пріоритетом радіотехнічного факультету.
У 1959 році на РТФ почалися роботи по створенню потужних підсилювальних ламп біжучої хвилі та фундаментальним теоретичним дослідженням у цьому напрямку, які привели до визначення умов оптимальної взаємодії електронного пучка 3 полем біжучої хвилі в уповільнюючій системі.

Наукові роботи за закритою тематикою ВМФ СРСР на факультеті розпочалися в 1946 р. В 1963 р. проф. Н. П. Воллернером була створена потужна проблемна лабораторія, яка в подальшому трансформувалася в ОКБ «Шторм». В той час лабораторія налічувала до 150 штатних працівників.

На радіотехнічному факультеті в той час виконується значний об'єм наукових досліджень по теорії кіл. Великий внесок в розвиток теорії кіл зробив професор Ярослав Карпович Трохименко. Так, у 1957 році ним була опублікована перша радянська робота з сучасної методики аналізу транзисторних кіл. Він розробив метод узагальнених чисел і його модифікації для символьного аналізу лінійних електронних кіл. Подальші дослідження з теорії кіл проводились проф. Олександром Івановичем Рибіним та ст. викл. Миколою Ігоровичем Ястребовим.

У 50-ті роки також проводилися дослідження 3 промислового застосування струмів НЧ, антенної техніки, фазометрії, феритовим термісторам, продовжувалися роботи з розроблення уповільнюючих систем для електронних прискорювачів.

У 60-ті роки на факультеті було організовано наукову групу (керівник - доц. Юрій Павлович Гудзенко), яка розробляла електронні НВЧ пристрої керування поляризацією та фазою вихідного сигналу. Проводилися розробки хвилеводних конструкцій керування фазою, електродинамічних систем потужних електронних НВЧ пристроїв та прискорювачів заряджених частинок.

У 1968 р. на факультеті було створено кафедру конструювання і виробництва радіоапаратури. Завідувачем кафедри став доц. Юрій Вікторович Михацький.

У 70-ті роки на факультеті отримала розвиток твердотільна електроніка, розроблено методи розрахунку генераторів та підсилювачів міліметрового діапазону для хвиль на лавино-пролітних діодах і 
діодах Ганна. Також було організовано галузеву лабораторію акустоелектроніки Міністерства електронної промисловості СРСР (науковий керівник проф. І.М. Гранкін). Виконано ряд робіт для оборонного комплексу СРСР.

У 1971 р. під керівництвом доц. Олександри Яківни Бокринської (каф. ТОР) було створено проблемну лабораторію радіотехнічних елементів та пристроїв, у якій плідно розвивався науковий напрям «Функціональна електроніка». Співробітники цієї лабораторії (доц. О. Я. Бокринська, проф. Я. К. Трохименко, доц. А. В. Кисляковський, доц. С. М. Кущ, с.н.с. Є.В. Кудінов, с.н.с. В. П. Ілясов, с.н.с. В.І. Цимбал і с.н.с. Г. М. Шаламов) у 1982 році стали лауреатами Державної премії УРСР.

У 1975 році група викладачів та наукових співробітників кафедри радіопередавальних пристроїв - проф. В. П. Тараненко, доц. В.І. Правда, доц. С. М. Дяченко, доц. В.І. Шевченко, с.н.с. М. В. Дереновський - стали лауреатами Державної премії УРСР за створення і впровадження у серійне виробництво потужної лампи біжучої хвилі.

У 1976 році на РТФ (каф. ТОР) створено галузеву науково-дослідну лабораторію надвисокочастотної твердотільної електроніки та радіовимірювальної техніки. В лабораторії створено ряд нових твердотільних пристроїв на новій елементній базі, зокрема, діелектричних резонаторах. Керівника лабораторії проф. М. Ю. Ільченка у складі групи спеціалістів із галузевих інститутів у 1983 році удостоє Державної премії УРСР, а в 1989 році Державної премії СРСР в області науки і техніки.

У 80-ті рр. на факультеті виконано ряд надважливих НДР та НДДКР з оборонної тематики. В цей час штат кафедри теоретичних основ радіотехніки налічував 25 викладачів та 220 наукових співробітників, інженерів і техніків. Групу з розроблення електродинамічних систем очолив проф. В.I. Найденко. Проф. Ф.Ф. Дубровка організував та очолив наукову групу зі створення нової антенної техніки.

У 1991 році співробітники проблемної лабораторії (каф. ТОР) с.н.с. В.І. Цимбал, доц. О. Я. Бокринська, с.н.с. В. П. Гололобов, с.н.с. Крилов, н.с.
М.Г. Іщенко отримали премію Ради Міністрів СРСР. В тому ж році за створення пристроїв та систем міліметрового діапазону довжин хвиль проф. В. П. Тараненко, проф. В.І. Правда, проф. Є.А. Мачуський, доц. Л. А. Ткаченко, ст. викл. М. Ю. Омельяненко, ст. викл. О. В. Турєєва були удостоєні премії Ради Міністрів СРСР.

Сьогодні до складу радіотехнічного факультету входить чотири кафедри: теоретичних основ радіотехніки (зав. каф. проф. Федір Федорович Дубровка), радіотехнічних пристроїв та систем (зав. каф. проф. Сергій Якович Жук), радіоприймання та оброблення сигналів (зав. каф. доц. Андрій Валерійович Мовчанюк) та кафедра радіоконструювання та виробництва радіоапаратури (зав. каф. проф. Свгеній Андрійович Нелін).

За останні десять років викладачами радіотехнічного факультету було видано 21 монографію, 8 підручників та велику кількість навчально-методичних посібників. У 2012 році двоє викладачів радіотехнічного факультету - проф. O.I. Рибін та доц. В. С. Вунтесмері, у складі авторських колективів отримали державні премії України в галузі науки і техніки за цикл підручників «Основи теорії кіл» (у двох частинах) та «Електродинаміка та поширення хвиль» (у двох частинах).

За останні десятиліття на радіотехнічному факультеті було виконано значний об'єм наукових досліджень в рамках 39 науково-дослідних робіт, захищено 26 дисертацій, із них 2 - докторські.

На факультеті (каф. ТОР) потужно працює визнана у світі наукова школа теорії й техніки антенних систем під керівництвом проф. Ф. Ф. Дубровки [3-8]. Виконано ряд особливо важливих науково-дослідних і дослідно-конструкторських робіт за державними замовленнями МОН України, МО України, СЗРУ України та інших центральних відомств України. Тематика цих робіт відноситься до розробок теорії і техніки новітніх мікрохвильових пристроїв і антенних систем різного призначення, супутникових інформаційних систем, нових принципів, методів і способів радіоелектронного захисту літальних апаратів і кораблів на основі поляри- 
заційних ефектів, нових телекомунікаційних систем та радарів різного призначення.

Створено теорію поляризаційних перетворень радіосигналів лінотропними середовищами, на основі якої запропоновано нові принципи, методи i способи поляризаційної адаптації радіосистем добування, перетворення та руйнування інформації, а також принципово нові системи радіоелектронного подавлення зенітно-ракетних комплексів протиповітряної оборони.

Запропоновано і розроблено нові високоефективні методи аналізу і синтезу антен та пристроїв мікрохвильової техніки. Розроблено антенну систему вітчизняного комплексу дальньої радіотехнічної розвідки стратегічного призначення «Кольчуга», антенну систему корабельного багатофункціонального радарного комплексу «Мінерал - ME1», а також низку великих дзеркальних антенних систем діаметром від 5 до 12 м для земних станцій супутникових інформаційних систем, які стали предметом експорту високотехнологічної наукоємної продукції України в низку зарубіжних країн.

Створено унікальну крупногабаритну багатопроменеву та багатодіапазонну антенну систему земної станції комплексу радіоелектронної розвідки космічних апаратів, за що Указом Президента України від 23 серпня 2014 р. науковому керівникові роботи проф. Ф. Ф. Дубровці, с.н.с. В. М. Глушенко, н.с. М. М. Литвину, н.с. С. М. Литвину присуджено Державну премію України в галузі науки і техніки.

У 2018-2019 роках успішно виконана науково-дослідна робота за Державним замовленням «Розроблення системи високоточного автоматичного супроводу низькоорбітальних супутників дистанційного зондування Землі», в результаті якої створено і випробувано дослідний зразок новітньої системи автоматичного високоточного супроводу низькоорбітальних космічних апаратів на основі квазімоноімпульсного методу із багатомодовою обробкою сигналів.

Під керівництвом професора В. I. Найденка [9, 10] (каф. ТОР) у 2015-2018 рр. виконано роботу за Грантом G4992 «Long-Range Stand-off Microwave
Radar for Personnel Protection» (замовник NATO). Peзультати роботи будуть використані для побудови надширокосмугових радарів, які здатні виявляти, розрізняти та класифікувати приховану одягом людини зброю з метою протидії тероризму. За кошти гранту на факультет закуплене сучасне вимірювальне обладнання на суму більше 150 тис. євро.

На факультеті продовжуються наукові роботи 3 медичної радіоелектроніки. Під керівництвом проф. О. Б. Шарпана проведено розробки неруйнуючих томографічних засобів для визначення комплексних імпедансних та структурних параметрів просторово розвинених невзаємних об'єктів, багатофункціонального апаратно-програмного комплексу неінвазівної діагностики та сенергетичної терапії з валідації діагностично-терапевтичних ознак, багаточастотного комплексу діагностики нормального і критичного стану водного балансу людини за векторним аналізом параметрів електричного біоімпедансу. Науково-дослідна робота «Біотелеметрична система централізованої багатопараметричної експрес-діагностики та персонального моніторингу функціонального стану людини» в 2020 році визнана однією з найкращих в КПІ ім. Ігоря Сікорського.

Також на факультеті проводяться дослідження взаємодії електромагнітних полів з фізичними та біологічними об'єктами (проф. А. П. Яненко).

Під керівництвом проф. С. Я. Жука [11-15] виконуються дослідження 3 моделювання процесів обробки траєкторної інформації в системі захисту від малорозмірних безпілотних літальних апаратів (МБПЛА). Низька помітність МБПЛА обумовлює необхідність використання комплексної системи спостереження: активної радіолокаційної системи (РЛС), пасивної системи моніторингу на основі бездротових сенсорних мереж (БСМ), системи відеоспостереження (СB).

Для підвищення ефективності виявлення і супроводження маневруючого МБПЛА розробляються алгоритми послідовного виявлення траєкторі і адаптивного оцінювання параметрів його руху за даними РЛС, БСМ, СВ при наявності хибних, аномальних вимірювань і пропусків сигналів, а також 
ототожнення траєкторі, які поступають від різних джерел. Створення програмного комплексу моделювання процесів обробки траєкторної інформації дозволяе провести всебічний аналіз ефективності розроблених алгоритмів, формулювати вимоги до структури, топології розміщення та технічних характеристик комплексної системи спостереження.

На кафедрі РТПС створена і плідно працює наукова група (керівник - ст.викл. Михайло Юрійович Омельяненко) 3 розробки хвилевідно-планарних гібридно-інтегральних схем малошумних генераторів, змішувачів, фільтрів та інших функціональних вузлів, а також повністю планарних високоефективних приймачів-передавачів зв'язаних станцій і трансиверів систем широкосмугового доступу міліметрового діапазону довжини хвиль [16-18], які неодноразово експонувалися на виставках і впроваджені у виробництво.

У галузевій науково-дослідній лабораторії факультету (каф. РТПС) під керівництвом к.т.н., с.н.с. Сергія Васильовича Лєвого були розроблені прилади для неруйнівного дослідження поверхонь і середовищ [19]. В основу розробок покладено магнітооптичний метод візуалізації магнітних сигналограм за допомогою ферогранатових плівок 3 використанням ефекту Фарадея. Розроблені комплекси працюють вже в 20 країнах світу. Об'єм фінансування розробок лабораторії за останні роки перевищує 20 млн. грн.

На кафедрі РОС виконуються дослідження в області спектрального аналізу сигналів та завад, аналогових та цифрових методів і засобів оброблення та розпізнавання образів, імпедансної томографії [20, 21] (проф. О.І. Рибін, доц. І.О. Сушко), приймання та оброблення сигналів [22] (проф. С. Я. Калюжний), фізики і техніки потужного ультразвуку (доц. А. В. Мовчанюк).

Науковцями факультету (ст. викл. М. О. Першин, доц. Р. В. Антипенко, доц. С.Є. Мартинюк) розроблено бортову підсистему зв'язку та антенні системи першого українського наносупутника PolyITAN-1. У 2014 році супутник було виведено на орбіту і станом на 2020 рік він знаходиться в пра- цездатному стані, приймає команди 3 наземної станції та передає сигнали телеметрії.

Під керівництвом проф. Є.А. Неліна [23-25] проводиться розробка фізико-технічних основ наноелектронних кристалоподібних пристроїв обробки сигналів. Запропоновано узагальнений імпедансний підхід до аналізу кристалоподібних структур. На цій основі розроблено нові методи аналізу та моделі кристалоподібних структур та пристроїв. Перевага імпедансного підходу - фізична наочність, можливість синтезу структур з заданими характеристиками. Розроблено оригінальні технічні рішення високоефективних структур та пристроїв. Створено єдині фізико-технічні засади проектування наноелектронних кристалоподібних пристроїв.

На базі радіотехнічного факультету в 1996 році створено науково-дослідний центр (НДЦ) систем технічного захисту інформації «ТЕЗІС» (директор д.т.н. Михайло Іванович Прокофьєв). Центр виконує дослідження за пріоритетним напрямком «Інформаційні та комунікаційні технології», зокрема, за тематичним напрямком «Технології та засоби захисту інформації». Вони спрямовані на удосконалення нормативно-методичної та технічної бази системи захисту інформації в Україні, розроблення галузевих стандартів системи ТЗІ, технічних засобів захисту інформації та відповідно до ліцензії Держспецзв'язку надання послуг з створення комплексів захисту інформації на об’єкта інформаційної діяльності. У складі НДЦ у період з 1998 по 2010 р. функціонувала акредитована випробувальна лабораторія 3 сертифікації засобів технічного захисту інформації.

Фахівцями центру в період з 2008 по 2012 рр. виконані дослідження, розроблені системи керування процесом плавки металу в вакуумній електронно-променевій плавильній печі (з використанням електронних гармат із загальною потужністю споживання понад $3 \mathrm{MBT}$ ), які впроваджено у виробництво (2 у КНР, 1 у Японії і 2 в Україні).

За об'ємом фінансування робіт «ТЕЗІС» $є$ одним із лідируючих підрозділів науково-дослідної частини КПІ ім. Ігоря Сікорського. В НДЦ «ТЕЗІС» 
за держзамовленнями успішно виконано 10 науково-дослідних та дослідно-конструкторських робіт. НДЦ «ТЕЗІС» приймає участь у проведенні щорічних міжнародних науково-практичних конференцій в Україні і Болгарії, видає періодичний науково-технічний збірник «Правове, нормативне i метрологічне забезпечення системи захисту інформації в Україні» (головний редактор - проф. Віктор Іванович Найденко).

Факультет є одним 3 головних організаторів міжнародних конференцій з теорії і техніки антен «International Conference on Antenna Theory and Techniques» (голова/співголова проф. Ф. Ф. Дубровка), які регулярно (з 1995 р.) проводяться в Україні. Конференція підтримується IEEE та індексуєтьс у SCOPUS.

На базі радіотехнічного факультету щорічно проводяться науково-технічні конференції «Радіоелектроніка у XXI столітті» для студентів, аспірантів та молодих вчених, та міжнародна науково-технічна інтернет-конференція «Радіотехнічні поля, сигнали, апарати та системи (теорія, практика, історія, освіта)».

Результати наукових розробок радіотехнічного факультету впроваджуються в лабораторних роботах, практикумах та навчальних курсах. Висока практична підготовка студентів-радистів один із пріоритетів нашого факультету. Студенти факультету активно користуються можливістю ака- демічної мобільності в рамках міжнародної стипендіальної програми Еразмус+. Протягом останніх років відвідали університети-партнери в Італії, Іспанії, Люксембургу, Швеції. Факультет протягом останніх 5 років активно співпрацює 3 Празьким технічним університетом (електротехнічний факультет) в рамках обміну студентами - понад 20 студентів виконували там науково-технічні проекти.

У цьому номері журналу «Известия высших учебных заведений. Радиоэлектроника» представлено вибрані статті [7, 8, 18, 22] науково-педагогічних працівників радіотехнічного факультету КПІ ім. Ігоря Сікорського, які відображають досягнуті результати поточної наукової діяльності факультету в актуальних напрямках у ювілейний 90-й рік його існування.

\section{БІБЛПГРАФІЧНИЙСПИСОК}

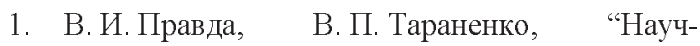
но-исследовательская работа на радиотехническом факультете КПИ," Известия вузов. Радиоэлектроника, Т. 41, № 7, C. 3-8, 1998, uri: http://radio.kpi.ua/ article/view/S002134701998070012

2. В. И. Правда, А. И. Рыбин, "Радиотехническому факультету НТУУ "КПИ" 80 лет (краткая историческая справка)," Известия вузов. Радиоэлектроника, Т. 53, № 11, C. 2-2, 2010, doi: $10.20535 / \mathrm{S} 002134701011$ $\underline{0000 .}$

3. S. Y. Martynyuk, D. O. Vasylenko, F. F. Dubrovka, A. G. Laush, "Novel microstrip antenna array for

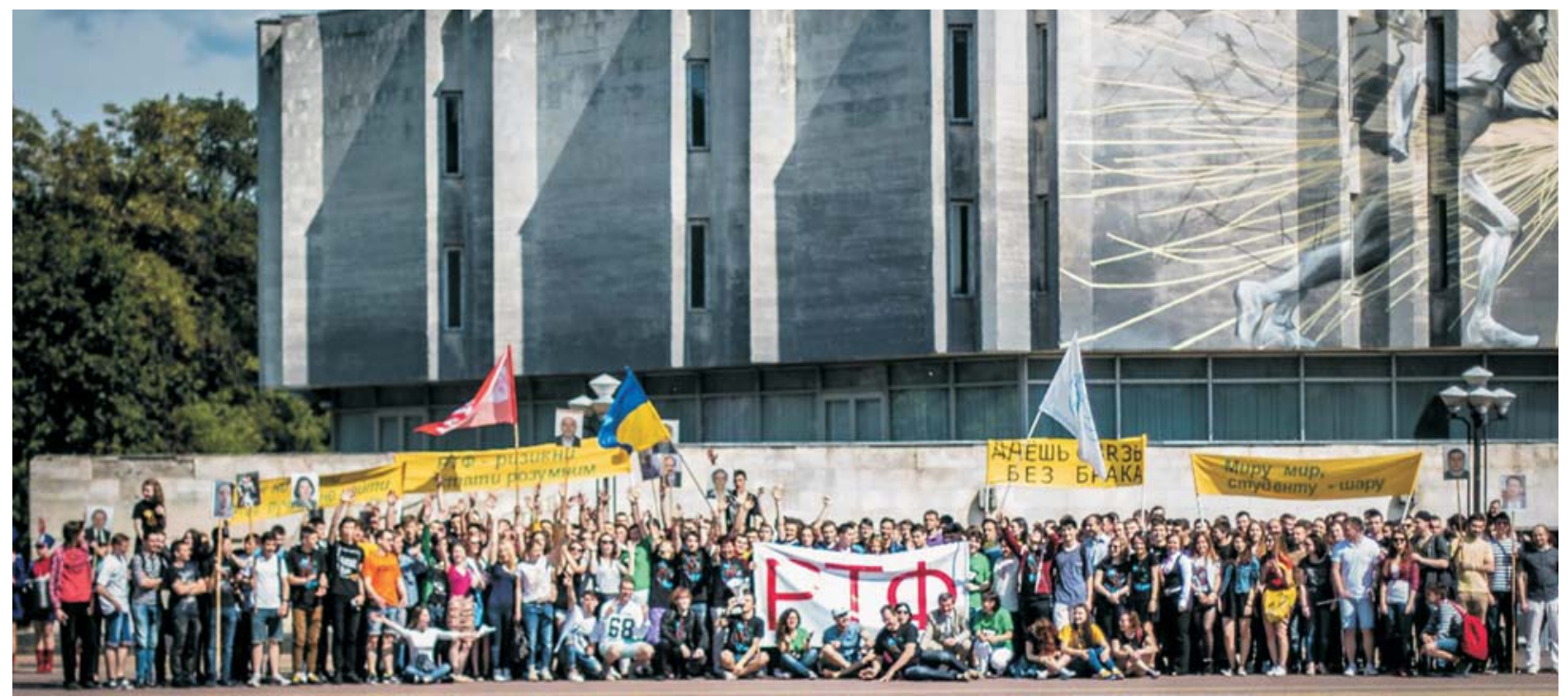


anti-jam satellite navigation system," Radioelectron. Commun. Syst., vol. 58, no. 3, pp. 97-106, 2015, doi: $10.3103 / \mathrm{S} 0735272715030012$.

4. O. E. Vydalko, F. F. Dubrovka, "Matching and radiation characteristics of a phased array based on quasi-Yagi planar antennas with an additional screen," Radioelectron. Commun. Syst., vol. 58, no. 4, pp. 157-165, 2015, doi: $10.3103 / \mathrm{S} 0735272715040032$.

5. F. F. Dubrovka, S. I. Piltyay, R. R. Dubrovka, M. M. Lytvyn, S. M. Lytvyn, "Optimum septum polarizer design for various fractional bandwidths," Radioelectron. Commun. Syst., vol. 63, no. 1, pp. 15-23, 2020, doi: $\frac{10.3103 / \mathrm{S} 0735272720010021 .}{6.0 .}$.

6. O. I. Pavlov, F. F. Dubrovka, "Evaluation of potential efficiency of speech coding using different parameters of linear prediction," Radioelectron. Commun. Syst., vol. 63, no. 9, pp. 449-464, 2020, doi: 10.3103/ S0735272720090010.

7. F. F. Dubrovka, S. I. Piltyay, "Ultrawideband microwave biconical high-gain antenna for dual-band syste$\mathrm{ms}$ of omnidirectional radio monitoring," Radioelectron Commun. Syst., vol. 63, no. 12, pp. 619-632, 2020, doi: $10.3103 / \mathrm{S} 0735272720120018$.

8. F. F. Dubrovka, S. I. Piltyay, Y. A. Ovsyanik, R. R. Dubrovka, "Eight-channel directional coupler of orthogonal H21 modes in circular waveguide for X-band quasi-monopulse antenna systems," Radioelectron. Commun. Syst., vol. 63, no. 12, pp. 656-665, 2020, doi: 10.3103/S0735272720120043.

9. V. I. Naidenko, "Uniform isotropic medium excitation with magnetic field step," Radioelectron. Commun. Syst., vol. 59, no. 6, pp. 274-279, 2016, doi: $\frac{10.3103 / \mathrm{S} 0735272716060078 \text {. }}{10 .}$

10. V. I. Naidenko, "Electromagnetic field energy balance for dispersive medium," Radioelectron. Commun. Syst., vol. 63, no. 10, pp. 553-560, 2020, doi: $10.3103 / \mathrm{S} 0735272720100052$.

11. S. Y. Zhuk, I. O. Tovkach, Y. Y. Reutska, "Adaptive filtration of radio source movement parameters based on sensor network TDOA measurements in presence of anomalous measurements," Radioelectron. Commun. Syst., vol. 62 , no. 2 , pp. 61-71, 2019, doi: $10.3103 / \mathrm{S} 073527271$ $902002 \mathrm{X}$

12. I. O. Tovkach, S. Y. Zhuk, "Adaptive filtration of parameters of the UAV movement based on the TDOA-measurement sensor networks," J. Aerosp. Technol. Manag., no. 11, p. e3519, 2019, doi: 10.5028/jatm.v11.1 062.

13. T. V. Baringolts, D. V. Domin, S. Y. Zhuk, V. $\mathrm{V}$. Tsisarzh, "Adaptive algorithm of maneuvering target tracking in complex jamming situation for multifunctional radar with phased antenna array," Radioelectron. Commun. Syst., vol. 62, no. 7, pp. 342-355, 2019, doi: $10.3103 /$ S0735272719070021.

14. S. Y. Zhuk, "Estimation of stochastic processes with random structure and Markov switches in discreet time (review)," Radioelectron. Commun. Syst., vol. 63, no. 10, pp. 505-520,2020, doi: 10.3103/S0735272720100015.

15. I. Tovkach, S. Zhuk, "Adaptive filtration of the UAV movement parameters based on the AOA-measurement sensor networks," Int. J. Aviat. Aeronaut. Aerosp., vol. 7, no. 3, 2020, doi: 10.15394/ijaaa.2020.1497.

16. M. Omelianenko, O. Turieieva, "24-channel Ku-band low-loss slotted waveguide power divider," Radioelectron. Commun. Syst., vol. 61, no. 6, pp. 242-245, 2018, doi: $\frac{10.3103 / \mathrm{S} 073527271806002 \mathrm{X}}{\mathrm{Y}}$

17. M. Y. Omelianenko, T. V. Romanenko, "High efficiency waveguide-planar amplifier with spatial powerp combining for frequency range 31-39 GHz," Radioelectron. Commun. Syst., vol. 62, no. 5, pp. 195-201, 2019, doi: $10.3103 / \mathrm{S} 0735272719050017$.

18. M. Y. Omelianenko, T. V. Romanenko, O. V. Turieieva, "Waveguide planar E-plane filter with ultra-wide stopband," Radioelectron. Commun. Syst., vol. 63, no. 12, pp. 650-655,2020, doi: 10.3103/S0735272720120031.

19. Y. Agalidi, P. Kozhukhar, S. Levyi, D. Turbin, "Enhanced magneto-optical imaging of internal stresses in the removed surface layer," Nondestruct. Test. Eval., vol. 30, no. 4, pp. 347-355, 2015, doi: $\underline{10.1080 / 10}$ 589759.2015.1044527.

20. И. А. Сушко, А. И. Рыбин, "Повышение быстродействия итерационной процедуры регуляризации по Тихонову при решении обратной задачи электроимпедансной томографии," Нзвестия вузов. Радиоэлектроника, Т. 58, № 9, с. 51, 2015, doi: $10.20535 / \mathrm{S} 00213470$ 15090058

21. А. И. Рыбин, А. Д. Мельник, Ю. Х. Нижебецкая, И. А. Супкко, С. Н. Литвинцев, "Классификацция одно- и двумерньх сигналов методами нормализации и нормального преобразования," Нзвестия вузов. Радиоэлектроника, Т. 59, № 1, с. 34, 2016, doi: $10.20535 / \mathrm{S} 0021$ 347016010027.

22. O. Kaliuzhnyi, "Cumulative distribution approximation of signal envelope in radio channels with arbitrary scattering," Radioelectron. Commun. Syst., vol. 63, no. 12 , pp. 633-649, 2020, doi: $10.3103 / \mathrm{S} 073527272012$ $\underline{002 X}$.

23. M. A. Gindikina, M. V. Vodolazka, E. A. Nelin. "Input impedance characteristics of barrier structures," Radioelectron. Commun. Syst., vol. 58, no. 7, pp. 329-336, 2015, doi: 10.3103/S0735272715070055.

24. P. S. Bidenko, E. A. Nelin, A. I. Nazarko, Y. F. Adamenko, "Quasi-lumped reactive elements based on crystal-like discontinuities," Radioelectron. Commun. Syst., vol. 58 , no. 11 , pp. 515-521, 2015, doi: $10.3103 / \mathrm{S} 0735$ 272715110059 .

25. E. A. Nelin, Y. L. Zinher, V. I. Popsui, "Low-pass filters based on crystal-like inhomogeneities," Radioelectron. Commun. Syst., vol. 61, no. 5, pp. 214-221, 2018, doi: $10.3103 / \mathrm{S} 0735272718050059$ 